\title{
Clinical and Demographic Characteristics of Children with Vitiligo: Retrospective Analysis of 105 Cases
}

\author{
Vitiligolu Çocukların Klinik ve Demografik Özellikleri : 105 Hastanın \\ Retrospektif Analizi
}

\author{
Ayse AKBAS, Fadime KILINC, Akın AKTAS
}

Ankara Şehir Hastaneleri, Dermatoloji Kliniği Ankara,Türkiye

\begin{abstract}
Objective: Vitiligo is a disease for which the cause is not clearly known public but is common and is characterised by depigmented macules. It's incidence rate ranges between $0.1-11 \%$.

Incidence among children is not known clearly but it has been reported that in half of the cases lesions start before the age of, and in 25\% they start before 10-14 years and it has different characteristics than that in adults. The aim of this study is to define the clinical and demographic characteristics of childhood vitiligo, identify the accompanying diseases and the treatment options that are provided.

Material and Methods: The files of 105 paediatric patients diagnosed with vitiligo in our hospital's dermatology department during the 2011-2018 period have been retrospectively examined. Age, gender, starting age, disease duration, lesion area, vitiligo type, family vitiligo history, blood tests and accompanying diseases have been recorded. Vitiligo types have been divided into 2 main groups, namely segmental and no segmental. Cases with generalized (vulgar), focal, acral, acrofacial vitiligo have been included in non-segmental vitiligo cases.

Results: $44.76 \%$ of the patients are female. The average age was $10.98 \pm 4.77$ years, the average age when the condition started was $9.63 \pm 4.53$ years and average duration of the disease was $19.19 \pm 19,60$ months (1.59 years). Number of cases in 0-2 age group was 7 (6.66\%), 3-5 age group was 10 (9.52\%), 6-11 age group was 32 (30.47\%), 12-18 age group was 56 (53.33\%). In terms of duration of the disease, $0-2$ months included 12 patients (11.42\%), 3-6 months included 11 patients (10.47\%), 7 months to 1 year included 9 patients (8.57\%), and over a year included 73 patients (6.52\%). With regards to the types of vitiligo, 6.66\% $(n=7)$ had segmental vitiligo, 92.38\% ( $n=97)$ had non-segmental vitiligo, $0.95 \%(n=1)$ had mixed type vitiligo. 53.60\% ( $n=52)$ of non-segmental vitiligo was focal vitiligo, $31.95 \%(n=31)$ was vitiligo vulgaris $7.21 \%(n=7)$ was acrofacial and $7.21 \%(n=7)$ was acral type. In terms of focal vitiligo 40.38\% ( $n=21)$ had cheek involvement, 23.07\% $(n=12)$ periorbital involvement, 11.53\% ( $n=6)$ perioral involvement, $7.69 \%(n=4)$ genital involvement and five cases $(9.61 \%)$ had multiple involvements. In $30.4 \%$ of the cases $(n=32)$, one or more coexisting disease has been observed to exist. Treatment options differed by age. While topical steroids and calcineurin inhibitors have been preferred in younger ages and in limited lesions, while in older ages and in more spread lesions phototherapy and systemic treatment methods have been practised.

Conclusion: This study is addressing the clinical and demographic characteristics of children with vitiligo as well as the practised treatment options. In contrast to other studies, this study has concluded more incidences among males. Regarding people in the early stages of vitiligo and in lesions localised in head-neck area, micro-therapy has been observed to be effective and calcineurin inhibitors have hastened repigmentation.
\end{abstract}

Key Words: Children, Epidemiology, Vitiligo

\begin{abstract}
(1)
AKBAȘA : :0000-0002-1626-1796

KILINÇ F : :0000-0001-9137-2675

AKTAS A

Conflict of Interest / Çıkar Çatışması: On behalf of all authors, the corresponding author states that there is no conflict of interest.

Ethics Committee Approval / Etik Kurul Onayı: Before the study, approval was taken from the local ethical committee (04.03.2017; 2019-059)

Contribution of the Authors / Yazarların katkısı: AKBAS A: Araștırma ve/veya makalenin hipotezini veya fikrini oluşturan, Araștırma/çalıșmanın sorumluluğunu üstlenmek, ilerlemenin seyrini denetlemek, Hasta takibinde sorumluluk almak, ilgili biyolojik malzemelerin toplanması, veri yönetimi ve raporlama, deneylerin yürütülmesi, Yazım ve dilbilgisi dıșında bilimsel olarak gönderilmeden önce makaleyi gözden geçirme. KILINC F: Sonuçlara ulașmak için planlama/metodoloj belirleme, Araștırma/çalıșmanın sorumluluğunu üstlenmek, ilerlemenin seyrini denetlemek, Hasta takibinde sorumluluk almak, ilgili biyolojik malzemelerin toplanmas, veri yönetimi ve raporlame, deneylerin yürütülmesi, Yazlm ve dibilgisi disnda bilimsel olarak gönderimeden önce makabyi gözden geçirme. AKTAS A: Sonuçari çalıșmaya dahil edilen hastaların sorumluluğunu almak.

How to cite / Atıf yazım şekli : Akbaș A, Kılınç F, Aktaş. Clinical and Demographic Characteristics of Children with Vitiligo: Retrospective Analysis of 105 Cases. Turkish J Pediatr Dis 2020;14:325-332.
\end{abstract}

Correspondence Address / Yazışma Adresi:

Ayşe AKBAŞ

Ankara Șehir Hastaneleri, Dermatoloji Kliniği Ankara, Türkiye

E-posta: ayseakbas62@yahoo.com.tr
Received / Geliş tarihi : 12.03.2019 Accepted / Kabul tarihi : 25.04.2019

Online published 14.05 .2019

Elektronik yayın tarihi

DOI: 10.12956/tchd.538826 


\section{Öz}

Amaç: Vitiligo toplumda nedeni tam olarak bilinmeyen, ancak sık görülen depigmente maküllerle karakterize bir hastalıktır. Sıklığı \%0.111 arasında değişmektedir. Çocukluk yaş grubunda prevelans tam olarak bilinmemekle beraber olguların yarısında 20 yaşından önce, \% 25'inde 10-14 yaş öncesi lezyonların başladığı ve erişkinlerden farklı olduğu bildirilmektedir. Bu çalışmada çocukluk çağında görülen vitiligonun klinik ve demografik özelliklerini tanımlamak, eşlik eden hastalıkları ve verilen tedavi seçeneklerini gözden geçirmek amaçlanmıştır.

Gereç ve Yöntemler: Hastanemiz dermatoloji bölümünde 2011-2018 yılları arasında vitiligo tanısı alan 105 çocuk hastanın dosyası retrospektif olarak incelendi. 18 yaş ve altı hastalar çalışmaya dahil edildi. Yaș, cinsiyet, bașlama yaşı, hastalık süresi, lezyon yerleşim yeri, vitiligo tipi, aile öyküsü, yapılan kan tetkikleri, eșlik eden hastalıklar kaydedildi. Vitiligo tipleri segmental ve nonsegmental olmak üzere 2 başlık altında toplandı. Nonsegmental vitiligolu hastalara generalize (vulgar), fokal, akral, akrofasiyal vitiligosu olan olgular dahil edildi.

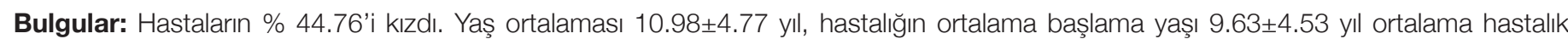
süresi $19.19 \pm 19.60$ ay (1.59 yıl) olarak hesaplandı. 0-2 yaș arası 7 (\% 6.66), 3-5 yaş arası 10 (\% 9.52), 6-11 yaș arası 32 (\%30.47), 1218 yaş arası 56 (\% 53.33) olgu bulundu. Hastalığın süresi açısından 0-2 ayda 12 hasta (\%11.42), 3-6 ayda 11 hasta (\%10.47), 7ay-1 yılda 9 hasta (\%8.57), bir yıldan fazla sürede 73 hasta (\%69.52) saptandı. Tiplerine göre oranladığımızda \% 6.66 ( $n=7)$ segmental vitiligo, \% 92.38 ( $n=97$ ) non segmental vitiligo, \% 0.95 ( $n=1$ ) miks tip vardı. Nonsegmental vitiligonun \%53.60 ( $n=52$ )'ı fokal vitililigo, \%31.95 ( $n=31$ )'i vitiligo vulgaris \%7.21 ( $n=7)$ 'i akrofasiyal, \%7.21 $(n=7)$ 'i akral tipteydi. Fokal vitiligo kapsamında \%40.38 ( $n=21)$ yanaklar, \%23.07 $(n=12)$ periorbital, \%11.53(n=6) perioral, \%7.69(n=4) genital, beş olguda (\%9.61) birden fazla tutulum mevcuttu. Olguların \% 30.4'ünde( n=32) eşlik eden bir veya birden fazla hastalık varlığı saptandı.Tedavi seçenekleri yaşa göre değişiklik göstermekteydi, topikal steroidler ve kalsinörin inhibitörleri erken yaşlarda ve sınırlı lezyonlarda tercih edilirken, daha ileri yaşlarda ve yaygın lezyonlarda fototerapi ve sistemik tedaviler uygulandığı saptandı.

Sonuç: Bu çalışmada vitiligolu çocukların klinik ve demografik özellikleri, uygulanan tedavi seçenekleri değerlendirilmiştir. Diğer çalışmalardan farklı olarak erkeklerde daha fazla olduğu görüldü. Özellikle vitiligosu yeni başlayan ve baş boyun bölgesine lokalize lezyonlarda mikroterapinin etkili olduğu, kalsinörin inhibitörlerinin repigmentasyonu hızlandırdığı izlendi.

Anahtar Sözcükler: Çocuk, Epidemiyoloji, Vitiligo

\section{INTRODUCTION}

Vitiligo is a disease for which the cause is not clearly known public but is common and is characterised by depigmented macules. It's incidence rate ranges between $0.1-11 \%(1,2)$. Incidence among children is not known clearly but it has been reported that in half of the cases lesions start before the age of, and in 25\% they start before 10-14 years and it has different characteristics than that in adults $(3,4)$. The cause of vitiligo is not clearly known but various factors such as genetic, neurohumoral, autoimmune and ototoxic metabolites are thought to be involved. It is reportedly seen in equal ratios in both genders but during childhood the ratio is more in girls (5).

Halder et al. report a difference in vitiligo between children and adults due to the existence of autoimmune endocrine disease, premature hair greying, increase in autoantibody incidence, different reactions to topical PUVA and other similar conditions (5).

There are a number of epidemiologic studies available regarding vitiligo in children (6-12). However, the number of epidemiologic studies on children with vitiligo in Turkey is very small $(11,12)$. The purpose of this study is to define the clinical and demographic characteristics of childhood vitiligo observed in Turkey, identify the accompanying diseases and the treatment options that are provided.

\section{MATERIAL and METHODS}

The files of 105 paediatric patients diagnosed with vitiligo in our hospital's dermatology department during the 2011-
2018 period have been retrospectively examined. Before the study, approval was taken from the local ethical committee (04.03.2017; 2019-059). Patients under the age of 18 have been included in the study. Age, gender, age at disease onset, disease duration, lesion area, vitiligo type, family vitiligo history and accompanying diseases have been recorded. As discussed in vitiligo consensus meeting, vitiligo types have been divided into 2 main groups, namely segmental and no segmental (13). Cases with generalized (vulgar), focal, acral, acrofacial vitiligo have been included in non-segmental vitiligo cases. Hemogram, fasting blood glucose, thyroid function tests, serum iron, ferritin, vitamin B12, folate and vitamin D levels have been recorded during the laboratory tests.

The statistical analysis of the study data has been performed by using SPSS 18.0 package program. Continuous variables have been indicated with average \pm standard deviation, while categorical variables have been indicated with percentages. Mann-Whitney $U$ test has been used for comparisons. Having a $p$ value lower than 0.05 has been deemed as statistically meaningful.

\section{RESULTS}

$44.76 \%$ of the patients are girls, $55.23 \%$ are boys. Boy/girl ratio is $1.23: 1$. The average age of the patients was $10.98 \pm 4.77$ years, the average age when the condition started was $9.63 \pm 4.53$ years and average duration of the disease was $19.19 \pm 19.60$ months. Average age of girls was $11.06 \pm 4.43$, and average age of boys was $10.93 \pm 5.07$, and no average age difference has been observed between genders $(p=0.869)$. 
Table I: Clinical and Demographic Characteristics of Vitiligo Patients Per Age Group.

\begin{tabular}{|c|c|c|c|c|c|c|c|}
\hline & $\begin{array}{l}\text { Our Study } \\
\text { Turkey }\end{array}$ & $\begin{array}{l}\text { Habib et } \\
\text { al.(10) } \\
\text { Pakistan }\end{array}$ & $\begin{array}{c}\text { Nicolaidou } \\
\text { et al.(7) } \\
\text { Greece } \\
\end{array}$ & $\begin{array}{c}\text { Aksoy et } \\
\text { al.(11) } \\
\text { Turkey }\end{array}$ & \begin{tabular}{|c|} 
Hu Z.et \\
al.(8) \\
China \\
\end{tabular} & $\begin{array}{l}\text { Mutahari } \\
\text { et al.(9) } \\
\text { Kuwait } \\
\end{array}$ & $\begin{array}{c}\text { Handa et } \\
\text { al.(6) } \\
\text { India } \\
\end{array}$ \\
\hline Total number of patients R/P & $105-R$ & $157-\mathrm{R}$ & $112-R$ & $63-\mathrm{R}$ & $541-P$ & $88-P$ & $625-\mathrm{R}$ \\
\hline $\begin{array}{l}\text { Girl ratio } \\
\% \text { boy/girl ratio }\end{array}$ & $\begin{array}{c}44.8 \\
1.23: 1\end{array}$ & $\begin{array}{c}56 \\
1: 1.13\end{array}$ & $\begin{array}{c}60.70 \\
-\end{array}$ & $\begin{array}{c}57 \\
-\end{array}$ & $\begin{array}{c}49.40 \\
-\end{array}$ & $\begin{array}{c}56.80 \\
-\end{array}$ & 57.1 \\
\hline $\begin{array}{l}\text { Starting age (years) } \\
\text { Average age (years) }\end{array}$ & $\begin{array}{c}8.60 \\
11.1\end{array}$ & $\begin{array}{r}6.53 \\
-\end{array}$ & $\begin{array}{c}6.62 \\
-\end{array}$ & $\begin{array}{c}8.70 \\
10.2\end{array}$ & $\begin{array}{c}7.20 \\
-\end{array}$ & $\begin{array}{c}6.20 \\
-\end{array}$ & $\begin{array}{l}6.20 \\
-\end{array}$ \\
\hline $\begin{array}{l}\text { Most frequent } \\
\text { vitiligo type }\end{array}$ & Focal & Vulgar & & Vulgar & & & Vulgar \\
\hline Most frequent localization & Head, face & $\begin{array}{l}\text { Head, } \\
\text { neck }\end{array}$ & - & - & - & - & Head, neck \\
\hline Vitiligo duration (years) & 1.56 & - & - & 1 & - & - & - \\
\hline Focal (\%) & 49.52 & 26 & & 37.30 & - & - & 14.40 \\
\hline Vulgar (\%) & 29.52 & 52 & 11.50 & 47.50 & - & - & 78.40 \\
\hline Acral (\%) & 6.66 & 1.90 & 69.6 & & & & \\
\hline Acrofacial (\%) & 6.66 & 4.50 & 9 & 17.60 & & - & 1.60 \\
\hline Segmental (\%) & 6.66 & 12 & 6.60 & 15.30 & & - & 4.60 \\
\hline Mixed (\%) & 0.95 & $\begin{array}{c}1.30 \\
\text { Universal }\end{array}$ & & - & - & & \\
\hline Halo nevus (\%) & 1.90 & & & & + & & 4.40 \\
\hline Leukotrichia (\%) & 7.61 & & & & & & 12.30 \\
\hline Family history (\%) & 9.52 & 31 & 8 & 16 & 11 & 27.3 & 12.2 \\
\hline Coexisting diseases & $\begin{array}{c}\text { IDA (19) } \\
\text { Vit DD (15) } \\
\text { VitB12DA (6) } \\
\text { Hypothyroidism(3) } \\
\text { Asthma (1) } \\
\text { Coeliac disease(1) } \\
\text { Vasculitis (1) } \\
\text { P. stenosis (1) } \\
\text { Chronic otitis (1) } \\
\text { Immune } \\
\text { deficiency (1) }\end{array}$ & & $\begin{array}{c}\text { AA } \\
\text { Thyroid D } \\
\text { RA } \\
\text { Psoriasis } \\
\text { IBD } \\
\text { Atopic } \\
\text { dermatitis }\end{array}$ & $\begin{array}{c}\text { Anaemia(13\%) } \\
\text { Asthma (6), } \\
\text { Atopic } \\
\text { Dermatitis } \\
\text { (3-22.5\%) } \\
\text { Thyroid D } \\
10.5 \% \\
\text { Halo nevus }\end{array}$ & $\begin{array}{c}\text { AA } \\
\text { Halo nevus }\end{array}$ & $\begin{array}{c}\text { Anaemia } \\
\text { AA DM } \\
\text { Atopy }\end{array}$ & $\begin{array}{c}\text { AA(2) } \\
\text { DM(1) } \\
\text { Addison(1) } \\
\text { PV(1) } \\
\text { Thyroid D (1) } \\
\text { PS(1) }\end{array}$ \\
\hline
\end{tabular}

$\boldsymbol{R}=$ Retrospective, $\boldsymbol{P}=$ Prospektif, $\boldsymbol{A} \boldsymbol{A}=$ Alopecia areata, $\boldsymbol{P V}=$ Pemphigus vulgaris, $\boldsymbol{P S}=$ Poliglanduler syndrome, Thyroid $\boldsymbol{D}=$ Thyroid disease, $\boldsymbol{D} \boldsymbol{M}=$ Diabetes mellitus, $\mathbf{I B D}=$ Irritable bowel disease $\boldsymbol{P}$. stenosis= Pulmonary stenosis, $\mathbf{I D A}=\mid$ ron deficiency anaemia $\boldsymbol{V i t} \mathbf{D} \boldsymbol{D}=V$ itamin $d$ deficiency, VitB12DA=Vitamin B12 deficiency anaemia

Patients have been divided into 4 groups depending on their ages; age 0-2 (baby), age 3-5 (play age), age 6-11 (school child) and age 12-18 (adolescent). The distribution of the cases in terms of age groups was as follows: $0-2$ age group $6.66 \%$ $(n=7), 3-5$ age group $9.52 \%(n=10), 6-11$ age group $30.47 \%$ $(n=32)$ and $12-18$ age group $53.38 \%(n=56)$.

In terms of duration of the disease, $0-2$ months included 12 patients (11.42\%), 3-6 months included 11 patients (10.47\%), 7 months to 1 year included 9 patients (8.57\%), and over a year included 73 patients (69.52\%).

With regards to the types of vitiligo, 6.66\% $(n=7)$ had segmental vitiligo, 92.38\% ( $n=97)$ had non-segmental vitiligo, 0.95\% $(n=1)$ had mixed type vitiligo. 53.60\% ( $n=52)$ of non- segmental vitiligo was focal vitiligo, $31.95 \%(n=31)$ was vitiligo vulgaris
$7.21 \%(n=7)$ was acrofacial and $7.21 \%(n=7)$ was acral type

There was no statistical difference between genders in terms of lesion type and disease duration $(p=0.953$ and $p=0.151$. The clinical and demographic characteristic per age-group of the patients and the treatment options are provided in Table I.

\section{DISCUSSION}

Vitiligo is a dermatosis present with depigmentation in skin and mucosa. In Turkey, studies on children with vitiligo are mostly assessed together with adult and child cases and the number of studies addressing children only is very few $(11,12)$. Our study has been conducted with this purpose and it has been 
Table II: Comparison of our study with the literature.

\begin{tabular}{|c|c|c|c|c|c|c|c|c|}
\hline $\begin{array}{l}\text { Patient group and } \\
\text { number of patients }\end{array}$ & $\begin{array}{l}\text { Gender } \\
\text { (M/F) }\end{array}$ & $\begin{array}{l}\text { Average } \\
\text { age }\end{array}$ & Onset & $\begin{array}{c}\text { D. } \\
\text { duration }\end{array}$ & V. type & $\begin{array}{l}\text { Coexisting } \\
\text { diseases }\end{array}$ & $\begin{array}{l}\text { Family } \\
\text { history }\end{array}$ & Treatment method \\
\hline Total 105 cases $\%$ & $58 / 47$ & 11 years & $\begin{array}{c}8.6 \\
\text { years }\end{array}$ & $\begin{array}{l}1.56 \\
\text { years }\end{array}$ & $\begin{array}{l}\text { Focal (52) } \\
\text { Vulgar (31) } \\
\text { Acral (7) } \\
\text { Acrofacial (7) } \\
\text { Segmental (7) } \\
\text { Mixed (1) }\end{array}$ & & 10 & \\
\hline $\begin{array}{l}0-2 \text { age }(7) \\
6.66 \%\end{array}$ & $3 / 4$ & 10.10 & $\begin{array}{c}6.70 \\
\text { months }\end{array}$ & $\begin{array}{l}3.40 \\
\text { months }\end{array}$ & $\begin{array}{l}\text { Vulgar (5) } \\
\text { Genital (2) }\end{array}$ & IDA (2) & - & $\begin{array}{l}\text { Local treament, TS } \\
\text { Drug-free monitoring }\end{array}$ \\
\hline $\begin{array}{l}3-5 \text { age }(10) \\
9.52 \%\end{array}$ & $7 / 3$ & $\begin{array}{l}3.90 \\
\text { years }\end{array}$ & $\begin{array}{l}2.30 \\
\text { years }\end{array}$ & $\begin{array}{l}1.90 \\
\text { years }\end{array}$ & $\begin{array}{l}\text { Segmental (2) } \\
\text { Vulgar (4) } \\
\text { Focal (3) } \\
\text { Acral (1) }\end{array}$ & $\begin{array}{l}\text { Asthma (1) } \\
\text { Pulmonary } \\
\text { Stenosis (1) }\end{array}$ & $\begin{array}{c}3 \\
1 \text { degree } \\
2 \text { degree }\end{array}$ & $\begin{array}{c}\text { Local treatment } \\
\text { Topical steroid (TS) } \\
\text { Calcineurin inhibitors (Cl) }\end{array}$ \\
\hline $\begin{array}{l}6-11 \text { age (32) } \\
30.47 \%\end{array}$ & $15 / 17$ & 8.20 years & $\begin{array}{l}7.90 \\
\text { years }\end{array}$ & $\begin{array}{l}1.20 \\
\text { years }\end{array}$ & $\begin{array}{l}\text { Segmental (3) } \\
\text { Focal (16) } \\
\text { Vulgar (10) } \\
\text { Acrofacial (2) } \\
\text { Acral (1) } \\
\text { Leukotrichia (5), } \\
\text { Halonevus (2) }\end{array}$ & $\begin{array}{c}\text { Vit DD(10) } \\
\text { IDA(8) } \\
\text { Vit B12DA(1) } \\
\text { Vasculitis (1) } \\
\text { Hypothyroidism } \\
\text { (1) } \\
\text { 1- Immune } \\
\text { deficiency (1) }\end{array}$ & $\begin{array}{c}(5) \\
1-1 \text { degree } \\
4-2 \text { degree }\end{array}$ & $\begin{array}{c}\text { Local treatment (6-TS, CI) } \\
\text { Antioxidant treatment(3) } \\
\text { General narrow band } \\
\text { UVB(1) } \\
\text { Local narrow band O (1) } \\
\text { Micro phototherapy }(10)\end{array}$ \\
\hline $\begin{array}{l}12-18 \text { age }(56) \\
53.38 \%\end{array}$ & $33 / 23$ & $\begin{array}{l}14.70 \\
\text { years }\end{array}$ & $\begin{array}{l}12.60 \\
\text { years }\end{array}$ & 1.85 & $\begin{array}{l}\text { Segmental (3) } \\
\text { Focal (31) } \\
\text { Vulgar (12) } \\
\text { Acral (5) } \\
\text { Acrofacial (5) }\end{array}$ & $\begin{array}{c}\text { DEA(9) } \\
\text { Vit DE (5) } \\
\text { Vit B12 } \\
\text { deficiency (5) } \\
\text { Coeliac } \\
\text { disease(1) } \\
\text { Hypothyroidism } \\
\text { (2) } \\
\text { Cr.otitis(1) }\end{array}$ & $\begin{array}{c}\text { (2) } \\
1 \text { degree (1) } \\
1 \text { degree (1) }\end{array}$ & $\begin{array}{c}\text { Local treatment (6- } \\
\text { Calcineurin inh) } \\
\text { Depo steroid(56) } \\
\text { Antioxidant oral } \\
\text { treatment (3) } \\
\text { Local narrow band } \\
\text { UVB treatment (4) } \\
\text { Microphototherapy } \\
\text { (32-average } 11 \text { sessions) } \\
\text { General narrow } \\
\text { band UVB (5) } \\
\text { Patient no treatment (3) }\end{array}$ \\
\hline
\end{tabular}

O: Onset, D: Disease, V: Vitiligo, TS: Topical steroid, CI: Calcineurin inhibitors, Cr: Chronic, Vit: Vitamin IDA: Iron deficiency anaemia

Vit DD:Vitamin d deficiency, VitB12DA:Vitamin b12 deficiency anaemi

compared with some studies in literature (Table II)(6-11). The age at disease onset has been defined to be between 6.208.70 in a number of studies(6-10,14-17). Similarly, the age at disease onset was 9.63 in our study. The earliest vitiligo In terms of focal vitiligo $40.38 \%(n=21)$ had cheek involvement, $23.07 \%(n=12)$ periorbital involvement, $11.53 \%(n=6)$ perioral involvement, $7.69 \%(n=4)$ genital involvement and $3.84 \%(n=2)$ had scalp involvement. There were one cases each of brow and neck involvement (0.95\%) while five cases had multiple involvements (9.61\%). Halo nevus has been observed at 1.90 $\%(n=2)$ and leukotrichia has been observed at $7.61 \%(n=8)$. Family history was $9.52 \%(n=10)$, ratio in immediate family was $2.85 \%$ while in second- degree relatives the ratio was $6.66 \%$.Laboratory records indicated $18 \%(n=19)$ of low iron level, $14.28 \%(n=15)$ of low vitamin D level, $5.71 \%(n=6)$ of low vitamin B12 level and 2.86\% $(n=3)$ of thyroid test abnormality (hypothyroidism).Forty-nine coexisting systemic diseases have been observed in 32 cases. $18.09 \%(n=19)$ iron deficiency anaemia, 14.2\% ( $n=15)$ vitamin D deficiency, $5.7 \%(n=6)$ vitamin B12 deficiency anaemia (VBA), $2.8 \%(n=3)$ hypothyroidism have been observed while in addition, there was a single case (0.95\%) each of the following; asthma, chronic otitis, pulmonary stenos, coeliac disease, vasculitis and immune deficiency.

Treatment options differed by age. While topical steroids and calcineurin inhibitors have been preferred in younger ages and in limited lesions, while in older ages and in more spread lesions phototherapy and systemic treatment methods have been practised.

Starting age has been defined as 1 month. Kayal et al.'s (15) youngest diagnosed patient was 6 months old, while a study conducted in China reported 8 babies born with vitiligo (8). Various previous studies have obtained different results from different age groups. The rates were as follows; under 4 years of age $16 \%, 4-8$ years old $41-49 \%, 8-12$ years old $26-56$ $\%$ and $12-19$ years old $15 \%(6,8,10,15)$. Results of our study 
are similar for 0-5 and 6-10 years old, but those for the 1218 year olds are different. While some authors report that the majority of their cases is aged between $6-12,53.38 \%$ of the cases in our study was aged between 12-18 (18). The reason could be delayed arrival of the patients to us. In this sense, it is highly important for the family practitioners to refer the patient to dermatology.

Previous studies have reported more incidences of vitiligo in girls $(2,5,6,15,17,19)$. Our study, on the other hand, had a conclusion slightly in favour of boys, $55.23 \%$, having a similarity with the study by Alzolibani et al.(20). Various studies have concluded a family history existence of 1.3-46 \% in patients with vitiligo $(2,6,8,9,11,16,20,21)$. The existence of family history enhances the idea of genetic factors playing a role in pathogenesis. In people with a family history vitiligo has been reported to start at an earlier age $(2,3,20)$. According to Alzolibani et al. (20), the existence of family history is less frequent in focal type. The ratio of family history has been defined as $9.52 \%$ in our study: In $2.85 \%(n=3)$ of the cases there was a vitiligo history in immediate family while in $6.66 \%(n=7)$ had the same in second degree relatives. In literature vitiligo in immediate family has been reported in different ratios ranging between 7 and 35.50 $\%(6,20,22)$. Wang et al. (21) have found family history in a rate of $2.50 \%$ in second degree relatives. The reason for vitiligo has not been clearly understood. Several factors such as genetic, neurohumoral, ototoxic may be involved. The existence of autoimmune diseases and the high level of some autoantibodies is supportive of the autoimmune hypothesis.

A number of studies have reported a coexistence of vitiligo and autoimmune disease in a rate of $30-25.30 \%$ (23). Some authors have stated that non-segmental vitiligo, in particular, has more accompanying diseases (2-4). Autoimmune thyroiditis, alopecia areata, diabetes mellitus (DM), Addison disease and pernicious anaemia are among the autoimmune diseases accompanying vitiligo $(2,3)$. In 32 cases of our study (30.4\%) there were 49 coexisting pathologies. A number of studies conducted in Turkey on adult and paediatric patients with vitiligo reported the existence of accompanying diseases in similar ratios (40-45\%) and they also mostly reported $21 \%$ of iron deficiency anaemia and $4.90-12 \%$ of vitamin B12 deficiency anaemia (24.25). In our study, covering children only, $18.09 \%$ (19 cases) of iron deficiency anaemia and 5.71\% $(n=6)$ vitamin B12 deficiency anaemia have been observed. The ratio of observing thyroid pathology in patients with vitiligo is around $10-26 \%(6,14,19,23)$. In a study conducted by Zetting et al. (26) on 1096 adult patients with vitiligo the most common coexisting disease has been reported as thyroiditis. Similar to Aksoy et al.(11), this study has revealed lower rates $(2.85 \%$ $(n=3)$ of thyroid pathology, but some studies conducted in Turkey and covering both adults and children have reported higher rates, ranging between 17-27 \%, of thyroid antibody $(11,24,27)$. This is an indication that as one gets older, the possibility of developing autoimmune diseases, anaemia and thyroid pathologies in particular, is increased. Therefore, thyroid antibodies are also required to be monitored in patients with vitiligo (25). The opposite is also true. In other words, vitiligo rate is high in patients with thyroiditis too. According to Prindaville et al. (28), the possibility of developing vitiligo in patients with thyroiditis is $2.70 \%$. Uncu et al. (29), on the other hand, claim that thyroid disease is associated with the duration of vitiligo, but has nothing to do with the onset and also that the risk of thyroid disease is not increased in segmental type. Similarly, hypothyroidism in adolescence was also common in our study and it was not related to segmental type (12-18). Ertekin et al.(30) Observed $2.10 \%$ (in 3 cases) of vitiligo in their series of children with coeliac. There was only a single case monitored with coeliac disease diagnosis in our study. Furthermore, vitiligo has been observed to be accompanied by dermatoses such as psoriasis, liken planus and atopic dermatitis $(3,4)$. No other skin disease has been observed in our study.

It has been recently claimed that vitamin $D$ in patients with vitiligo is important in terms of secondary autoimmunity. In cases where the blood level is below $15 \mathrm{ng} / \mathrm{ml}$, the risk in other autoimmune diseases is reportedly is higher, hence there is a need to monitor this level. Particularly in early childhood, the relation between vitiligo and vitamin $D$ has been found to be more significant in children under 15 (31). The fact that $14.28 \%$ $(n=15)$ of the cases in our study had vitamin $D$ deficiency is supportive of this claim.

Vitiligo, in recent studies, is being categorized as extensive, localized, segmental, universal and non-segmental based on lesion distribution and prevalence. Segmental vitiligo has been observed more frequently in children, particularly in the 4-8 age group (4-32.60\%) $(5,6,8,19)$. This type of vitiligo is mostly observed in face, periorbital area and neck. Our study included a ratio of segmental type vitiligo (6.66\%) that is similar to that reported by similar Marinho et al.(18). In addition, one of the cases was in a mixed structure containing segmental and generalize vitiligo.

The most frequent non-segmental type vitiligo observed in children is generalized (78\%), followed by focal vitiligo (1). Focal vitiligo is seen in around 14-29\% of the cases (18). Some authors have reported that in children vitiligo is mostly located around the eye and neck, followed by lower extremity, torso, upper extremity and perianal are(15). In our study, nonsegmental vitiligo ratio is $92.38 \%$ and focal vitiligo is $49.52 \%$ $(n=52)$. Localization was mostly observed in cheeks, followed by the sides of the eyes and mouth. Kayal et al. (15) reported a periorbital zone involvement of $26 \%$ and our finding was $11.53 \%$. Gandi et al. (17) reported the most involvement was observed in torso.

Vitiligo vulgaris, or in other words generalized vitiligo, is diffused symmetrically around the face, neck, torso, extremity bone tips. It is observed in a ratio of 33-78 \% (15.18). Despite being the 
most frequent type both in adults and in children, it was the second most frequent in our study $(29.52 \%)(5,6,8,9,16,18)$. While acral type is involving the tip of extremities, while the acrofacial type involves the surrounding of the orifice and finger distal. It comprises 1-14 \% of all vitiligo $(15,18)$. Nejat et al. (32) reported a higher ratio of acrofacial type, by $27.60 \%$. Acral and acrofacial types have been observed at the same ratios in our study by a total of $13.32 \%$. Premature hair greying is also more common in children with vitiligo (5). Scalp involvement is around $12-26 \%$ and greying of hair (leukotrichia) occurs too $(2,15,20)$. Eight of the cases had (7.61\%) leukotrichia. Genital and oral mucosal involvement is rare. The ratio of reported cases is 0-13.80 \%(6). No oral mucosal involvement has been observed in our study. However, genital involvement was present in six of our patients, two with vulgar type and four focal. Some authors have stated that the perianal area could be the starting place for vitiligo (3).

The ratio of halo nevus in children with vitiligo is high. Some authors have stated that the existence of halo nevus and leukotrichia in segmental vitiligo poses a risk of generalization and halo nevus is more common in vitiligo with an early onset (3). However, there is no concrete evidence to indicate it as a symptom of vitiligo. A number of studies have reported halo nevus ratios ranging between 0.92-59\% $(2,3,15,33)$. Halo nevus has been observed in only 2 cases (1.96\%) in our study. Kobnerization has not been assessed as it has not been specified on patient legs.

Vitiligo etiopathogenesis is difficult to treat as it has not been fully understood. The purpose of treatment is to stop the progression of lesions and to facilitate re-pigmentation. Selection of treatment is based on the child's age, lesion localization, prevalence and family preference. It has impact on success in clinic type (34). Various treatment guides are being discussed (34- 38). With regards to vitiligo treatment, systemic, topical treatments (containing topical corticosteroid, topical vitamin $\mathrm{D}$ analogues and topical calcineurin inhibitors), phototherapy (narrow band UVB, PUVA, microphototherapy), depigmenting agents, surgical intervention are among the options (34-37). But none of them is fully satisfying. Besides, in $15-30 \%$ of the patients there is no reaction at all. In a number of studies, the first option provided to children with vitiligo was potent steroid creams and calcineurin inhibitors (18). Topical practises have yielded a success rate of 35-60 \% (34-37).

In our study, 0-2 years old babies have been either monitored without any treatment or treated short-term with topical steroid creams. Regarding children over the age of 2, the first option was using steroid creams for 2 week durations, with a week pause in between, in limited lesions for a total duration of 3 months. The combination of topical steroid and topical calcipotriol has been observed to reduce the atrophic side effects related to steroid. A number of studies have concluded a success rate of $26-75 \%$ in topical potent steroid practises(18,34).
Based on the treatment approach employed in our clinic, cases who did not give any reaction to treatments within 3 months have been provided with calcineurin inhibitors as an alternative treatment. These medications have less side effects than cortisone and thus helped the patient harmonization. A number of studies have reported a success rate of $76 \%$, particularly in vulgar and focal types (37). The reaction ratio to treatment could not be defined in our study but in general the outcomes were positive. The combined use of topical Calcineurin inhibitors and narrow band UVB treatment has yielded a synergic effect (37). In our study, we also witnessed that calcineurin inhibitors provided as part of phototherapy treatments is increasing the speed of repigmentation.

Topical vitamin $\mathrm{D}$ analogues are thought to have an impact by making an immunomodulation and melanogenesis stimulation through vitamin D receptors (34-37). A study on the subject has reported success in 10 cases out of 18 children (31). We have provided it as an alternative supplementary treatment to patients with vitiligo. As combines treatments have been provided to cases, their single efficiency could not be assessed.

In patients over the age of 12 and with rapid spreading vitiligo lesions, depo steroid (triamcinolone acetonide 40mg ) has been applied monthly, due to cytotoxic effects, for a total of 3 times. Based on the oxidative stress etiopathogenesis of vitiligo, all cases over the age of 12 have been given antioxidant treatment (capsule containing vitamin A,C,E and selenium) and oral vitamin $D$ preparations as supplemental treatment (36). Iron deficiency and vitaminB12 deficiency, observed during the tests, have been treated. Phototherapy has been reported to have positive effects in vitiligo treatment according to several studies. Narrow band UVB phototherapy is believed to be an effective and secure method in paediatric vitiligo. It is recommended for patients with an involvement area of over 2 $\%$ if topical treatment is not beneficial. However, it should not be used for more than 12 months (38).A number of studies have reported $44-78 \%$ of success rate with narrow band UVB treatment (38). Depending on the lesion conditions of the patients, local UVB, microphototherapy or general narrow band UVB treatments have been implemented. Treatment has been ceased at the end of 6 month if no reaction has been observed to treatment or at the end of the 12 month duration. In our study, the ratio of patients receiving local narrow band UVB treatment was $3.80 \%(n=4)$ and the ratio of patients receiving general narrow band UVB was $4.76 \%(n=5)$. These patients have received 100 treatment sessions over a period of around a year. The reason for the number of patients receiving phototherapy to be low could be because their vitiligo lesions are mostly in focal type or because the patients have refused it themselves. Microphototherapy UVB is only applied to lesions in target oriented treatment (37). Regarding the patients who had only localised lesions, such as the face, microphototherapy UVB treatment has been applied every fortnight. Microphototherapy has been applied to $30.47 \%(n=32)$ of the children with vitiligo. 
They received a total amount of treatment sessions ranging between 2 and 23, with an average of 11 sessions. Success rate was particularly higher in those with a lesion in the head neck area.

As most of the patients have been provided with more than one, or in other words with a combined treatment scheme, the success rate of repigmentation treatment options could not be calculated properly.

No reaction at all has been received from $15-30 \%$ of the patients with vitiligo but it should be kept in mind that there may be a possibility of $30 \%$ spontaneous remission. Thus it is not fully known whether repigmentation has occurred by itself or through treatment (2).

\section{CONCLUSION}

This study is addressing the clinical and demographic characteristics of children with vitiligo as well as the practised treatment options. The gender ratio among our patients was slightly in favour of males. The average age was 10.9 years, average age at disease onset was 9.63 years while the average disease duration has been calculated as 1.59 years.

Majority of the cases was aged between $12-18$. In $40 \%$ of the cases there was a coexisting pathology.

Non-segmental vitiligo was $92.38 \%$ while focal vitiligo was $49.52 \%$. Cheek localization was the most frequent. Particularly in lesions localised in head-neck area with new-onset vitiligo, micro-therapy has been observed to be effective and the calcineurin inhibitors given in between treatments to speed up repigmentation. Success rate was higher in combined treatments. Furthermore, the antioxidant treatments have been observed to be useful, increasing patient satisfaction.

Epidemiologic studies are not only important to determine the frequency of diseases but they are also required for the planning of effective health services. Therefore, being the first point of assessment, it is highly important for the family practitioners to refer the family so that treatment can start earlier and be effective.

\section{REFERENCES}

1. Silverberg NB. The Epidemiology of vitiligo. Curr Derm Rep 2015:4:36-43.

2. Phiske MM. Vitiligo in children: a birds eye view. Curr Pediatr Rev 2016;12:55-66.

3. Ezzedine K, Silverberg N. A Practical approach to the diagnosis and treatment of vitiligo in children. Pediatrics 2016;138. pii: e20154126.
4. Gianfaldoni S, Tchernev G, Wollina U Lotti J, Satolli F, França K, et al. Vitiligo in children: a better understanding of the disease.Open Access Maced J Med Sci 2018;6:181-4.

5. Halder RM. Childhood vitiligo. Clin Dermatol 1997;15:899-906.

6. Handa S, Dogra S. Epidemiology of childhood vitiligo: a study of 625 patients from North India. Pediatr Dermatol 2003;20:207-10.

7. Nicolaidou E, Antoniou C, Miniati A, Lagogianni E, Matekovits A, Stratigos A, et al. Childhood and later-onset vitiligo have diverse epidemiologic and clinical characteristics. J Am Acad Dermatol 2012;66:954-8.

8. Hu Z, Liu JB, Ma SS, Yang S, Zhang XJ. Profile of childhood vitiligo in China: an analysis of 541 patients. Pediatr Dermato 2006;23:114-6.

9. Al-Mutairi N, Sharma AK, Al-Sheltawy M, Nour-Eldin O. Childhood vitiligo: a prospective hospital-based study. Australas J Dermato 2005;46:150-3.

10. Habib A. Vitiligo in children: a distinct subset. J Coll Physicians Surg Pak 2016;26:173-6.

11. Aksoy F. Evans S,Karaduman A. Çocukluk çağında vitiligo: 63 vakanın prospektif olarak değerlendirilmesi.Turkiye Klinikleri J Dermatol 2008;18:67-71.

12. Arıcan O, Koc K, Ersoy L. Clinical characteristics in 113 Turkish vitiligo patients. Acta Dermatovenerol Alp Pannonica Adriat 2008;17:129-32.

13. Ezzedine K, Lim HW, Suzuki T, Katayama I, Hamzavi I, Lan CC, et al. Revised classification/nomenclature of vitiligo and related issues: the Vitiligo Global Issues Consensus Conference. Pigm Cell Melanoma Res 2012;25:E1-13.

14. Kartal D, Borlu M, Çınar SL, Kesikoğlu A, Utaş S. Thyroid abnormalities in paediatric patients with vitiligo: retrospective study. Postepy Dermatol Alergol 2016;33:232-4.

15. Kayal A, Gupta LK, Khare AK, Mehta S, Mittal A, Kuldeep CM. Pattern of Childhood Onset Vitiligo at a Tertiary Care Centre in South- West Rajasthan. Indian J Dermatol 2015;60:520.

16. Agarwal S, Ojha A, Gupta S. Profile of vitiligo in kumaun region of Uttarakhand, India. Indian J Dermatol 2014;59:209.

17. Gandhi S, Shamanur M, Shashikiran A R, Kusagur M, Sugareddy, Bhaskar V. A study of clinico-epidemiological and dermoscopic patterns of vitiligo in pediatric age group. Indian J Paediatr Dermatol 2017;18:292-8.

18. Marinho FS, Cirino PV, Fernandes NC. Clinical epidemiological profile of vitiligo in children and adolescents. An Bras Dermato 2013;88:1026-28.

19. Cho S, Kang HC, Hahm J. Characteristics of vitiligo in Korean children. Pediatr Dermatol 2000;17:189-93.

20. Alzolibani A. Genetic epidemiology and heritability of vitiligo in the Qassim region of Saudi Arabia. Acta Dermatovenerol Alp Panonica Adriat 2009;18:119-25

21. Wang X, Du J, Wang T, Zhou C, Shen Y, Ding X, et al. Prevalence and clinical profile of vitiligo in China: a community-based study in six cities. Acta Derm Venereol 2013;93: 62-5.

22. Pajvani U, Ahmad N, Wiley A, Levy RM, Kundu R, Mancini AJ, et al. The relationship between family medical history and childhood vitiligo. J Am Acad Dermatol 2006;55:238-44.

23. Narita T, Oiso N, Fukai K, Kabashima K, Kawada A, Suzuki T. Generalized vitiligo and associated autoimmune diseases in Japanese patients and their families. Allergol Int 2011;60:505-8.

24. Gönül M, Cakmak SK, Oğuz D, Gül U, Kiliç S. Profile of vitiligo patients attending a training and research hospital in Central Anatolia: a retrospectivestudy. J Dermatol 2012;39:156-9. 
25. Topal O, Duman H, Gungor S, Kocatürk E, Can P.Evaluation of the clinical and sociodemographic features of Turkish patients with vitiligo. Acta Dermatovenerol Croat 2016;24:124-9.

26. Zettinig G, Tanew A, Fischer G, Mayr W, Dudczak R, Weissel M. Autoimmune diseases in vitiligo: do antinuclear antibodies decrease thyroid volume? Clin Exp Immunol 2003;131: 347-54.

27. Afsar FS, Isleten F. Prevalence of thyroid function test abnormalitiesand thyroid autoantibodies in children with vitiligo. IndianJ Endocrinol Metab 2013;17:1096-9.

28. Prindaville B, Rivkees SA. Incidence of vitiligo in children with Graves'disease and Hashimoto's thyroiditis. Int J Pediatr Endocrinol 2011;1:18.

29. Uncu S, Yayli S, Bahadır S, Okten A, Alpay K. Relevance of autoimmune thyroiditis in children and adolescents with vitiligo. Int J Dermatol 2011;50:175-9.

30. Ertekin V, Selimoglu MA, Altinkaynak S. Celiac disease in childhood:evaluation of 140 patients. Eurasian J Med 2009;41:1547.

31. Zhang X, Wang W, Li Y, Wang H, Liu R, Zhu L. Serum 25-hydroxyvitamin $D$ status in chinese children with vitiligo: a casecontrol study. Clin Pediatr (Phila) 2018;57:802-5.
32. Nejad SB, Qadim HH, Nazeman L, Fadaii R, Goldust M. Frequency of autoimmune diseases in those suffering from vitiligo in comparison with normal population.Pak J Biol Sci 2013;16:570-4.

33. Kalkanli N, Kalkanli S. Classification and comparative study of vitiligo in Southeast of Turkey with biochemical and immunological parameters. Clin Ter 2013;164:397-402.

34. Driessche FV, Silverberg N. Pediatr current management of pediatric vitiligo. Drugs 2015; 17:303-13.

35. Taieb A, Alomar A, Böhm M, Dell'anna ML, De Pase A, Eleftheriadou V, et al. Vitiligo European Task Force (VETF); European Academy of Dermatology and Venereology (EADV); Union Europe'enne desMe'decinsSpécialistes (UEMS). Guidelines for the management of vitiligo: the European Dermatology Forum consensus. $\mathrm{Br} \mathrm{J}$ Dermatol 2013;168:5-19.

36. Gianfaldoni S, Wollina U, Tchernev G, Lotti J, França K, Lotti T. Vitiligo in children: a review of conventional treatments. Open Access Maced J Med Sci 2018;6:213-7.

37. Baykal L, Bahadır S. Çocuklarda vitiligo tedavsi ve yeni tedavi yaklaşımları. 2015 dermatoz /2/dermatoz doi:10.15624 dermatoz $15062 d 2$

38. Yazici S, Günay B, Bașkan EB, Aydoğan K, Saricaoğlu H, Tunali Ş. The efficacy of narrowband UVB treatment in pediatric vitiligo: a retrospective analysis of 26 cases. Turk J Med Sci 2017;47:381-4. 